\title{
The intensifying requirements for white clover cultivar change
}

\author{
P.T.P. CLIFFORD ${ }^{1}$, G.A. SPARKS ${ }^{1}$ and D.R. WOODFIELD ${ }^{2}$ \\ ${ }^{1}$ AgResearch, P.O. Box 60, Lincoln \\ ${ }^{2}$ AgResearch Grasslands, Private Bag 11008, Palmerston North
}

\begin{abstract}
For the last five years an average 14,761 ha of white clover has been grown for seed, with $77 \%, 8 \%$ and $15 \%$ sown in public cultivars, New Zealand and overseas proprietary cultivars, respectively. The area presently contaminated by proprietaries is estimated at 20,000 ha. New Zealand requirements for cultivar-change are more effective than OECD requirements. The five-year break period enables successful cultivar change in $90 \%$ of cases and is improved further when buried seed counts were used prior to sowing to indicate paddocks with unacceptable buried seed load. Current isolation distances appear adequate with virtually all foreign pollen deposition occurring within $24 \mathrm{~m}$ of the pollen source. Capture of additional public cultivar area (77\%) by proprietary cultivars will rely on increasing the seed yields of proprietary cultivars by approximately $25 \%$. This is realisable through greater attention to the environmental requirements of each cultivar and through better technology transfer between head licencees and growers.
\end{abstract}

Keywords: buried seed, crop areas, cultivar-change requirements, public cultivars, proprietary cultivars, seed production, Trifolium repens L., white clover

\section{White clover seed production statistics}

Areas in crop, percentage of total and average seed yields for public cultivars, New Zealand and overseas proprietaries for the seasons 1990-91 to 1994-95 are given in Table 1 (MAF Quality Management 199195). Over the last five seasons 14,761 ha was used annually for white clover seed production. Of this area $77 \%, 8 \%$, and $15 \%$ were sown in public cultivars (Huia and Pitau), New Zealand and overseas proprietary cultivars, respectively. Mean seed yields for the same

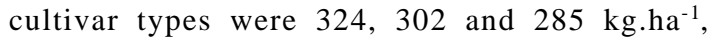
respectively. Variations in yield between years and in the area grown, however, indicate that seed yields commensurate with those of public cultivars can be obtained in each proprietary type. Proprietary cultivars commonly exhibit a marked reduction in yield in years with large increases in seed production areas. This reduction is associated with a combination of using growers with less awareness of the required skills and crops being grown in less suitable environments. These lower first harvest yields are frequently compensated for through retention of area to give high yielding second harvest crops. An example of this is evident for seed yield comparisons of New Zealand proprietaries between 1990-91 and 1992-93. Almost 80 additional new crops were required to double the area of Kopu and Tahora to 1488 ha. This resulted in a low average seed yield of $194 \mathrm{~kg} \cdot \mathrm{ha}^{-1}$ in 1991-92, but $438 \mathrm{~kg} \cdot \mathrm{ha}^{-1}$ in 1992-93 after the area in production was reduced (Table 1).

\section{Current and future land requirements}

The continuing erosion of traditional white clover seed production area through conversion to dairying and horticultural uses means that there is little scope in the

Table 1: Seed production area for Publics, New Zealand and Overseas Proprietaries for seasons 1990-91 to 1994-95 (MAF Seed Certification Statistics)

\begin{tabular}{|c|c|c|c|c|c|c|c|c|c|c|}
\hline \multirow[t]{3}{*}{ Seasons } & \multirow{2}{*}{\multicolumn{3}{|c|}{ New Zealand }} & \multirow{2}{*}{\multicolumn{3}{|c|}{$\begin{array}{l}\text { Cultivar Type } \\
\text { New Zealand }\end{array}$}} & \multirow{2}{*}{\multicolumn{3}{|c|}{ Overseas }} & \multirow{3}{*}{$\begin{array}{l}\text { Total } \\
\text { area } \\
\text { (ha) }\end{array}$} \\
\hline & & & & & & & & & & \\
\hline & $\begin{array}{c}\text { Area } \\
\text { ha }\end{array}$ & $\begin{array}{l}\% \text { of } \\
\text { total }\end{array}$ & $\begin{array}{l}\text { Yield } \\
\mathrm{kg} / \mathrm{ha}\end{array}$ & $\begin{array}{c}\text { Area } \\
\text { (ha) }\end{array}$ & $\begin{array}{c}\text { Proprietaries } \\
\% \text { of } \\
\text { total }\end{array}$ & $\begin{array}{l}\text { Yield } \\
\text { (kg/ha) }\end{array}$ & $\begin{array}{l}\text { Area } \\
\text { (ha) }\end{array}$ & $\begin{array}{c}\text { Proprietaries } \\
\% \text { of } \\
\text { total }\end{array}$ & $\begin{array}{l}\text { Yield } \\
\text { (kg/ha) }\end{array}$ & \\
\hline 1990-91 & 9898 & 82 & 385 & 722 & 6 & 343 & 1396 & 11 & 327 & 12016 \\
\hline $1991-92$ & 12283 & 73 & 381 & 1492 & 9 & 194 & 2930 & 18 & 420 & 16705 \\
\hline 1992-93 & 12271 & 77 & 284 & 867 & 5 & 438 & 2803 & 18 & 214 & 15941 \\
\hline 1993-94 & 12607 & 81 & 244 & 1071 & 7 & 234 & 1921 & 12 & 180 & 15599 \\
\hline 1994-95 & 10149 & 75 & $\mathrm{~N} / \mathrm{A}$ & 1540 & 11 & $\mathrm{~N} / \mathrm{A}^{\dagger}$ & 1856 & 14 & $\mathrm{~N} / \mathrm{A}$ & 13545 \\
\hline Means & 11442 & 77 & 324 & 1138 & 8 & 302 & 2181 & 15 & 285 & 14761 \\
\hline
\end{tabular}

$\dagger \mathrm{N} / \mathrm{A}=$ not available 
immediate future to reach the 25,000 ha crop obtained in 1982-83 (MAF Qual., 1983). Additionally the recent area in proprietaries, which averaged 3395 ha (Table 1), does not provide a true picture of the total land area involved. Given the range of crop rotation options available, white clover is only taken for seed in a particular paddock every three to four years. Approximately $1200 \mathrm{ha}$ of white clover are required to service a 100 MT market given an average yield of $300 \mathrm{~kg} \cdot \mathrm{ha}^{-1}$ and with 3.5 years between crops. This figure, extrapolated in terms of the average tonnage of the top twelve proprietaries grown over the last five years (763 MT) gives an estimated 'contaminated' area of 9200 ha (MAF Qual., 1995). Taking into account land used for lesser proprietaries over that time and possibly another dozen new releases, several with high land requirements, then current land requirement is probably closer to 20,000 ha. It is therefore very timely that the appropriateness of our present certification requirements for cultivar change and other factors likely to enhance change procedures and seed yield is reviewed.

\section{Development of cultivar change requirements}

The intensifying requirements for white clover (Trifolium repens $\mathrm{L}$.) change from growing public varieties to growing proprietaries had its beginning in 1985. Prior to that date, only Grasslands Huia and Grasslands Pitau (released 1975) were grown under the current OECD change regulations. OECD regulations involved three years between cultivars, but no cultural practice allowing positive identification of contaminants within the new crop.

Subsequent to the release of Pitau, AgResearch (then DSIR, Grasslands Division) became increasingly aware of the limitations of the OECD scheme in ensuring genetic purity of the resultant seedline. Research into formulation of an 'indicative' buried seed sampling technique found that more than three years were needed to ensure genetic integrity (Lancashire et al. 1985).

Grasslands Tahora (released 1983) was the first cultivar contracted on the basis of a five-year cultivarchange protocol. Paddock choice was based on buried seed count and sowings were at $45 \mathrm{~cm}$ row spacings to facilitate adequate certification inspection. In $1984 \mathrm{MAF}$ Quality Management amended the New Zealand seed certification requirements to five years out of clover with the initial new cultivar crop to be sown at spacings of no less than $30 \mathrm{~cm}$ (MAF Qual., 1984). Not only were more stringent quality control measures introduced for Grasslands cultivars, but they also applied for the first European cultivars multiplied under licence in New Zealand that year.
Over the next decade to 1995 , the industry has been inundated with additional cultivars, rising from three to 38 , of which only nine are returning royalties to New Zealand breeding organisations. The remainder are simply being multiplied for re-export. Of note has been a lack of industry moves to curtail further additions to the list of overseas cultivars eligible for multiplication. When coupled with current New Zealand breeding demands for specialist markets, obtaining suitable crop area per-cultivar to meet market requirements up to and beyond the year 2000 is at best uncertain.

\section{Effectiveness of cultivar change requirements}

\section{Isolation distance and genetic purity}

A distinctive overseas white clover was multiplied under existing cultivar-change requirements in the 1994-95 season (Table 2). An area of 0.1 ha was established and isolated from the nearest white clover cultivar by $400 \mathrm{~m}$; both areas being stocked with separate beehives. The initial buried seed count was 0 seeds per 50 cores, and seedling quadrat counts at field inspection were also zero. The crop was inter-row sprayed with occasional variants within the row hand rogued. Due to the greater chance for foreign pollen being deposited at the margins of this small crop, bulk samples were taken from the outside one metre of the crop and randomly throughout the crop for progeny testing. These samples were compared with the overseas nucleus seed sown and two overseas multiplications of the same cultivar multiplied under OECD regulations. Hand roguing of off-types gave a marked improvement $(0.04 \%$ vs $0.76 \%)$ in purity over the parent seedline (Table 2). Even slight peripheral foreign pollen introduction only gave half the contamination level of the parent seedline $(0.32 \%$ vs $0.76 \%$ respectively). In dramatic contrast to the results gained under New Zealand certification requirements were those for crops multiplied under OECD regulations. In this instance, the increase in contamination levels was 350 and 822 fold (Table 2). These results provide strong justification for the retention of MAF Quality Management's current change requirements.

Table 2: Effect of New Zealand compared to OECD seed certification requirements on genetic purity of resultant seedlines for a distinctive overseas white clover cultivar.

\begin{tabular}{clc}
\hline Line & \multicolumn{1}{c}{ Description } & $\begin{array}{c}\text { Contamination } \\
(\%)\end{array}$ \\
\hline 1 & Overseas parent line & 0.76 \\
2 & NZ requirement - bulk sample & 0.04 \\
3 & NZ requirement - edge sample & 0.32 \\
4 & Overseas commercial - sample 1 & 2.66 \\
5 & Overseas commercial - sample 2 & 6.25 \\
\hline
\end{tabular}


During the 1993-94 and 1994-95 seasons, pollen movement by honeybees was studied near Lincoln, using two commercial crops of six and seven hectares, respectively (Woodfield et al. 1994). A $50 \mathrm{~m}^{2}$ area of a dominant genetic marker (feathermark) was planted in the centre of each crop and stocked with a single beehive. Inflorescences available for pollination were tagged weekly along eight radial transects, ranging from 2 to $112 \mathrm{~m}$ and 1 to $250 \mathrm{~m}$ from centre to crop edge for first and second seasons, respectively. Seeds were collected from tagged inflorescences and 187,900 and 170,200 seedlings screened for leaf mark frequency in 1994 and 1995, respectively (Table 3). Virtually no pollen spread occurred beyond $24 \mathrm{~m}$ of the pollen source. Furthermore, other bees sited within the crop servicing area had no impact by way of increased pollen spread in the direction of hive placement. The feathermark pollen deposition

Table 3: Decline in the frequency of feathermark genetic marker in the crop as distance from the pollen source increases.

\begin{tabular}{rcccc}
\hline $\begin{array}{c}\text { Distance from } \\
\text { pollen source } \\
(\mathrm{m})\end{array}$ & \multicolumn{2}{c}{$\begin{array}{c}\text { Number of seedlings } \\
\text { screened }\end{array}$} & $\begin{array}{c}\text { Number and cumulative } \\
\text { frequency of genetically marked } \\
\text { progeny }\end{array}$ \\
\hline \multicolumn{1}{c}{1994} & 1995 & 1994 & 1995 \\
\hline 2 & - & 13080 & - & $395(57 \%)$ \\
4 & 14882 & 12339 & $110(71 \%)$ & $161(80 \%)$ \\
6 & 14598 & 13286 & $18(83 \%)$ & $60(88 \%)$ \\
8 & 14382 & 12506 & $8(88 \%)$ & $35(93 \%)$ \\
10 & 14558 & 12745 & $6(92 \%)$ & $18(96 \%)$ \\
12 & 14736 & 11630 & $3(93 \%)$ & $5(97 \%)$ \\
16 & 14396 & 12149 & $1(94 \%)$ & $5(97 \%)$ \\
24 & 15937 & 12110 & $2(95 \%)$ & $11(99 \%)$ \\
32 & 13998 & 10950 & $5(98 \%)$ & $3(99 \%)$ \\
48 & 15118 & 12072 & $1(99 \%)$ & 0 \\
64 & 14406 & 11895 & $1(99 \%)$ & 0 \\
78 & 13776 & 11755 & 0 & 0 \\
96 & - & 2746 & - & 0 \\
112 & 15016 & 8824 & 0 & $1(99 \%)$ \\
136 & 12150 & - & $1(100 \%)$ & - \\
184 & - & 3091 & - & 0 \\
240 & - & 2952 & - & 0 \\
250 & - & 1652 & - & 0 \\
\hline
\end{tabular}

area showed no distinctive change over two distinctly different growing seasons.

This information not only verifies the suitability of current isolation distances but also reinforces the requirement to have hives intimately associated with the crop to promote effective pollination levels. However, where two cultivars are only $50 \mathrm{~m}$ apart, beehives should be placed at the extremes of both crops to counter any likely drift associated with flowering pattern differences.

Five year paddock history and buried seed counts The need for a five-year break requirement relates to the timespan required for decay/elimination of seed contributed from the previous cultivar harvest losses, to a level where purity of the change cultivar is not compromised. Initial research (Clifford et al. 1990) has shown a timespan of five years was needed to meet first generation quadrat requirements for all harvest loss calculations; based on the range of seed losses reported by Clifford and McCartin (1985) (Table 4). Even then, inter-row spraying was essential to meet the mandatory requirement of no more than one per quadrat for the four higher loss treatments. The need for a five-year break period was reinforced from data for the 1989-90 season when $4 \%$ (10 crops) failed first generation standards and an additional $30 \%$ (29) of the paddocks submitted to the MAF Seed Testing Station returned buried seed counts greater than 10 seeds/50 cores and were withdrawn (Clifford et al. 1990). Of this latter $30 \%$, probably less than half would have passed certification if proceeded with. Therefore, the fiveyear break confidence-of-success level

Table 4: Seed loss from the soil burden over time and its relationship to established plants, calculated from regression slopes, for common cultivation and direct-drilled responses (from Clifford et al. 1990). Densities which meet first generation certification standard of one offtype or less per $10 \mathrm{~m}^{2}$ are in bold type.

\begin{tabular}{|c|c|c|c|c|c|c|c|c|}
\hline \multicolumn{9}{|c|}{ Seed numbers and established plant density $/ \mathrm{m}^{2}$ seasons } \\
\hline \multirow[t]{2}{*}{ Harvest loss (kg/ha) } & \multicolumn{2}{|c|}{------- Year 1 ------- } & \multicolumn{2}{|c|}{------- Year 3 ------- } & \multicolumn{2}{|c|}{------- Year 5 ------- } & \multicolumn{2}{|c|}{------- Year 6 ------- } \\
\hline & Seed & Plants & Seed & Plants & Seed & Plants & Seed & Plants \\
\hline 300 & 50000 & 4890 & 2030 & 47 & 240 & 0.45 & 83 & 0.040 \\
\hline 240 & 40000 & 3920 & 1630 & 38 & 190 & 0.36 & 66 & 0.035 \\
\hline 180 & 30000 & 2940 & 1220 & 28 & 140 & 0.27 & 50 & 0.027 \\
\hline 120 & 20000 & 1960 & 815 & 19 & 96 & 0.18 & 33 & 0.018 \\
\hline 60 & 10000 & 980 & 410 & 9 & 48 & 0.09 & 17 & 0.009 \\
\hline 6 & 1000 & 98 & 41 & 0.9 & 5 & 0.009 & 2 & 0.0009 \\
\hline
\end{tabular}


appears to be about $90 \%$; which does not include crops withdrawn due to poor establishment.

Efforts to reduce the five-year break have resulted in unacceptably high rejection rates. In autumn 1995 six cultivar change crops were sown in paddocks ranging from 3 to 4 years after Huia (Table 5). Only two crops (33\%) met buried seed quadrat requirements at the initial inspection; one third year and one fourth year crop. However, the third year crop was subsequently rejected because of high contamination levels. This is further evidence of the inadequacy of current buried seed sampling and further endorses the current five-year break until consistent results can be proven.

Presently, there is no accurate pre-sowing sampling which would allow the five-year mandatory break period to be reduced. Buried seed counts were developed firstly, as a quick test to indicate paddocks likely to meet the requirements for high grade seed multiplication and secondly, to indicate those which would not meet certification standards in that year. Current sampling technology is based on a total sample mass which can easily and cost effectively be handled in a laboratory. The standard sampling procedure involves taking five separately bagged rows each of 10 cores $(25 \mathrm{~mm}$ in diameter) to a depth of $50 \mathrm{~mm}$. Cores are collected after the last deep working of any intended cultivarchange site. Standards recommended for breeders seed are 0 to 3 seeds per 50 cores $\left(0-120\right.$ seeds. $\left.\mathrm{m}^{-2}\right)$ and 4 to 6 seeds per 50 cores for basic seed (160-240 seeds. $\mathrm{m}^{-2}$ ) (Anon 1987). In hindsight, 0-120 seeds. $\mathrm{m}^{-2}$ appears to be the only density capable of meeting the requirements of high grade multiplication (Table 3 ).

Problems associated with present buried seed sampling technique are two-fold. Firstly, samples forwarded to laboratories vary in mass from "a thimble to a sack full" (pers. comm., MAF Seed Testing Station; N.Z. Seedlab). Standard procedures are not being adhered to, therefore results are highly variable and do not allow any finite determination of success level. Secondly, the fixed sampling procedure takes no account of paddock area ( 1 to 50 ha) let alone distance between header offal trails (up to two-fold difference); these being the zones of higher seed load deposition (Clifford \& McCartin 1985). As a consequence, extremes of 100-fold in magnitude can never be consistently measured because of sampling error.

Presently unknown, is what opportunity exists to develop a reliable, useable, and enforceable buried seed sampling technique which would consistently account for both area and offal trails. To be completely functional, consistency would also have to take account of the breakdown of seed dormancy over time (1 to 5 years);
Table 5: Effect of reduced duration and cropping history on success of cultivar change for six white clover crops.

\begin{tabular}{ccccc}
\hline $\begin{array}{c}\text { Years from } \\
\text { last cultivar }\end{array}$ & $\begin{array}{c}\text { Interval } \\
\text { management }\end{array}$ & $\begin{array}{c}\text { Contaminants } \\
\text { per quadrat }\end{array}$ & Passed $^{1}$ & Rejected \\
\hline 3 & Annual cult. & 0.8 & $\boldsymbol{J}^{2}$ & $\checkmark$ \\
3 & Annual cult. & 10.7 & & $\checkmark$ \\
3 & Annual cult. & 60.1 & $\checkmark$ \\
3 & Annual cult. & 20.3 & $\checkmark$ \\
3 & Annual cult. & - & $\checkmark$ & \\
4 & Annual cult. & 0.4 & \\
1 & A total quadrat average of no more than 1 contaminant per $10 \mathrm{~m}^{2}$ for \\
2 & First Generation Seed \\
\hline
\end{tabular}

including rotational and seasonal (i.e. temperature and moisture fluctautions) variation on decay levels (Clifford et al. 1990). Only when all these criteria can be met could the present five year cultivar-change requirement be reduced.

\section{Seed production potential and consistency}

For all AgResearch cultivars from Grasslands Demand onwards, final parent selection and recombination has been based on commercial seed production area evaluations. This procedure ensures that new cultivars have genetic stability through a five-generation multiplication system with a built-in assurance that yield is at least comparative with existing cultivars. In this manner, prospective multipliers know that these cultivars are price-competitive and thereby have an assured lifespan in a predominantly commodity-trade market. In contrast, little or no information exists on the seed yield potential for newly-registered overseas proprietaries within our range of environments.

Seed yields vary according to cultivar choice and management skills from 100 to $1000 \mathrm{~kg} \cdot \mathrm{ha}^{-1}$ with a current national average of $300 \mathrm{~kg} \cdot \mathrm{ha}^{-1}$ (Table 1). Consistently good producers average over $400 \mathrm{~kg} \cdot \mathrm{ha}^{-1}$ across all crops and up to $600+\mathrm{kg} \cdot \mathrm{ha}^{-1}$ in good seasons. Therefore, considerable scope exists for more effective use of the existing white clover cropping area. By improving grower understanding of cultivar choice and crop management technology, there is an immediate potential to lift average yields to $400 \mathrm{~kg} \cdot \mathrm{ha}^{-1}$. This increase would free up $25 \%$ or, in rotational terms, about 5000 ha of the current area.

Production consistency is a function of cultivar yield potential and requires matching the cultivar with environmental and cultural variables for optimal flower. For example, small-leaf cultivars generally produce higher seed yields than larger-leaved cultivars under high fertility. Producing consistently high seed yields, 
however, is dependent on an awareness of, and an ability to modify management according to both, seasonal and individual paddock requirements.

Sowing date and weed control are major limitations to white clover seed production. Early sowings are a pre-requisite to ensure satisfactory plant development prior to flowering. Improved establishment is achieved where clover can be sown after early-harvested crops such as ryegrass, brassicas or peas. In contrast, late harvesting of cereals in poor climatic conditions and/or late availability of cultivar seed can delay sowing and restrict the critical autumn establishment period. Satisfactory weed control has two essential components. Firstly, greater emphasis should be placed on eradicating weeds, which cannot be controlled in clover, in the preceding five-year crop rotation. Secondly, the release of the herbicide Preside (Flumetsulam $800 \mathrm{~g}_{\mathrm{kg}} \mathrm{kg}^{-1}$ ) in October 1995, should reduce many of the existing establishment weed problems, including vital dressing problem weeds such as sheep's sorrel (Rumex acetasella L.) and suckling clover (Trifolium dubium L.). Addition of another new herbicide (Jaguar (25g. $1^{-1}$ diflufenican + bromoxynil $250 \mathrm{~g} .1^{-1}$ ) to be registered in autumn 1996) should enable a significant number of traditional Huia growers to undergo cultivar change. Weed control within a row-spaced change crop, rather than a fiveyear break period or price per $\mathrm{kg}$, has frequently been given as the reason for not changing cultivars.

\section{Technology transfer}

The sale of the Ministry of Agriculture and Fisheries Advisory Service (now Agriculture New Zealand) and a total movement to user pays, has led to a significant change in the responsibilities for technology transfer. While a proportion of this role has been absorbed by private consultants, ultimate responsibility will now sit with the immediate beneficiaries.

For example, new 'Grasslands' cultivar development is now funded from joint capital injection through AgResearch - Head Licencee Agreements. The investment returns on the final product (or cultivars) are in the form of royalties (AgResearch) and profit margins (Head Licencee). The ultimate venture success is therefore measured in terms of market share as related to product availability at a competitive price. This places the responsibility for technology transfer with the head licencee and AgResearch. Developing grower confidence in their ability to achieve profitable yields through regular consultation and encouragement is the key to obtaining sufficient areas and thereby a long-term market focus.

"White clover seed production is not a science, rather it is the art of understanding and applying a range of sciences to effect a consistent satisfactory seed yield."

\section{Conclusions}

1. Since $1982-83(25,000+$ ha $)$ the clover seed production area has halved due to more-profitable land use alternatives.

2. The number of cultivars in certification rather than area pose both the major present and future problem.

3. Current cultivar-change requirements are adequate with only one possibility for modification - an improved buried-seed count.

4. Effective area use is related to improved grower efficiency.

5. Release of new broadacre herbicides should overcome current problem weeds which limit establishment and first season yield. This may accelerate the transition from public cultivars to proprietaries by up to $40 \%$.

6. Acquiring sufficient suitable land for any cultivar will, more and more, reflect the closeness of the association between head licensee and grower to the benefit of both parties.

\section{Acknowledgements}

Ivan Baird and Anna Coventry, AgResearch, Lincoln; Greig Cousins, AgResearch Grasslands, Palmerston North for technical assistance. The many seed growers for honest comment over the years.

\section{References}

Anon. 1987. Analytical Services. pp. 8-16. In: Annual Report 1986, Official Seed Testing Station, Ministry of Agriculture and Fisheries, Palmerston North, New Zealand.

Clifford, P.T.P.; McCartin, S.J.M. 1985. Effects of preharvest treatment and mower and header types on seed loss and hard seed content at mowing, recovery and separation when harvesting a white clover seed crop. New Zealand Journal of Experimental Agriculture 13: 307-316.

Clifford, P.T.P.; Baird, I.J.; Grbavac, N.; Sparks, G.A. 1990. White clover soil seed loads: effect on requirements and resultant success of cultivar change crops. Proceedings of New Zealand Grassland Association. 52: 95-98.

Lancashire, J.A.; Rolston, M.P.; Scott, D.J. 1985. Contamination of white clover seed crops by buried seeds. pp. 61-65. In: Hare, M.D.; Brock, J.L. (eds). Producing Herbage Seeds. Grassland Research and Practice Series No. 2. 
MAF Quality Management. 1984. Seed Certification and Quality Control, MAF Qual., Christchurch.

MAF Quality Management. 1983. Seed Certification statistics 1982-83, MAF Qual., Christchurch, 42 pp.

MAF Quality Management. 1991. Seed Certification statistics 1990-91, MAF Qual., Christchurch, 63 pp.

MAF Quality Management. 1992. Seed Certification statistics 1991-92, MAF Qual., Christchurch, 62 pp.

MAF Quality Management. 1993. Seed Certification statistics 1992-93, MAF Qual., Christchurch, 62 pp.
MAF Quality Management. 1994. Seed Certification statistics 1993-94, MAF Qual., Christchurch, 68 pp.

MAF Quality Management. 1995. Seed Certification statistics 1994-95, MAF Qual., Christchurch, 69 pp.

Woodfield, D.R.; Clifford, P.T.P.; Baird, I.J.; Cousins, G.R. 1995. Gene flow and estimated isolation requirements for transgenic white clovers. Proceedings 3rd international symposium on biosafety results of field tests of genetically modified plants and microorganisms. pp. 509-514. 